\title{
ARTIKEL TENTANG PERSATUAN DAN KESATUAN
}

\author{
Antonius Oktavianus \\ NIM. 2111B0038 \\ Institut Ilmu Kesehatan STRADA Indonesia \\ Email: fianaye20@gmail.com
}

\begin{abstract}
ABSTRAK
Bangsa Indonesia dikenal sebagai bangsa majemuk, ditandai dengan banyaknya etnis, suku, agama, budaya, kebiasaan, di dalamnya. Di sisi lain, masyarakat Indonesia dikenal sebagai masyarakat multikultural, masyarakat yang anggotanya memiliki latar belakang budaya (cultural background) beragam. Sebuah negara akan menjadi kuat kokoh apabila masyarakatnya memiliki semangat persatuan dan kesatuan. Menengok sejarah bahwa persatuan dan kesatuan bangsa terbentuk dari proses yang tumbuh dari unsur-unsur sosial budaya masyarakat Indonesia sendiri, yang ditempa dalam jangkauan waktu yang lama sekali. Prinsipnya dihayati dari berbagai keberagaman pahami lalu kita amalkan, demi membangun Persatuan dan kesatuan mencakup upaya memperbaiki kondisi kemanusiaan lebih baik dari hari kemarin. Semangat untuk senantiasa memperbaiki kualitas diri ini amat sejalan dengan perlunya menyiapkan diri menghadapi tantangan masa depan yang kian kompetitif.
\end{abstract}

\section{PENDAHULUAN}

\section{A Latar Belakang}

Bangsa Indonesia dikenal sebagai bangsa majemuk, ditandai dengan banyaknya etnis, suku, agama, budaya, kebiasaan, di dalamnya. Di sisi lain, masyarakat Indonesia dikenal sebagai masyarakat multikultural, masyarakat yang anggotanya memiliki latar belakang budaya (cultural background) beragam. Kemajemukan dan multikulturalitas mengisyaratkan adanya perbedaan. Bila dikelola secara benar, kemajemukan dan multikulturalitas menghasilkan energi hebat. Sebaliknya, bila tidak dikelola secara benar, kemajemukan dan multikulturalitas bisa menimbulkan bencana dahsyat.

Nation and character building sebagai cita-cita membentuk kebudayaan nasional sebagai wahana pemersatu bangsa cenderung belum terwujud. Malah akhir-akhir ini semangat yang menjurus pada kesukubangsaan semakin bertambah besar sepertinya semangat mengutamakan paham suku-bangsa lebih beradab dan maju ketimbang suku-bangsa yang lainnya cenderung tumbuh. Padahal semangat kesukubangsaan yang lebih mengutamakan kebesaran sukubangsanya di tengah-tengah negara yang multikultur ini tentunya tidak sejalan dengan paham kebangsaan yang dikembangkan sejak negara ini berdiri. 
Pedoman kehidupan berbangsa dan bernegara yang sarat dengan itikad menjaga, melindungi, mempersatukan dan membangun bangsa untuk mampu meraih kemajuan adab, setara dengan bangsa-bangsa maju lainnya di dunia seolah-olah menjadi barang usang yang sudah ditinggalkan. Manifesto kultural Bhinneka Tunggal Ika yang merupakan tekad untuk membentuk kohesi sosial dan integrasi sosial, serta menyiratkan landasan mutualisme (kebersamaan, dalam perasaan maupun perilaku) dan kerjasama yang didasarkan atas kepentingan bersama dan perasaan kebersamaan, itu pun semakin pudar. Padahal makna dari manifesto kultural itu adalah ternanamnya perasaan saling memiliki dan menghargai sesama warganegara Indonesia, meski dengan latar belakang etnik dan kebudayaan yang berbedabeda.

Berdasarkan uraian diatas maka penulis tertarik untuk menulis artikel tentang persatuan dan kesatuan diantaranya; pengertian persatuan dan kesatuan bangsa, makna dan pentingnya persatuan dan kesatuan bangsa, prisip-prinsip persatuan dan kesatuan bangsa, nilai-nilai persatuan dan kesatuan, serta cara mewujudkan persatuan dan kesatuan bangsa.

\section{PEMBAHASAN}

\section{A Pengertian Persatuan dan Kesatuan Bangsa}

\section{a) Persatuan / Kesatuan:}

Persatuan/kesatuan berasal dari kata satu yang berarti utuh atau tidak terpecahbelah. Persatuan/kesatuan mengandung arti "bersatunya macam-macam corak yang beraneka ragam menjadi satu kebulatan yang utuh dan seras” (Heroick, 2019)

Jadi Sebuah negara akan menjadi kuat kokoh apabila masyarakatnya memiliki semangat persatuan dan kesatuan. Prinsipnya adalah keadaan satu atau tunggal yang menuntut adanya keterpaduan dari berbagai kebergaman dan kemajemukan bangsa indonesia.

b) Indonesia:

Mengandung dua pengertian, yaitu pengertian Indonesia ditinjau dari segi geografis dan dari segi bangsa. (Heroick, 2019)

\section{Beberapa pengertian dilihat dari:}

(a)Segi geografis, Indonesia berarti bagian bumi yang membentang dari $95^{\circ}$ sampai $141^{\circ}$ Bujur Timur dan $6^{\circ}$ Lintang Utara sampai 11o Lintang Selatan atau wilayah yang terbentang dari Sabang sampai Merauke. 
(b) Indonesia dalam arti luas adalah seluruh rakyat yang merasa senasib dan sepenanggungan yang bermukim di dalam wilayah itu.

(c) Persatuan dan kesatuan Bangsa Indonesia berarti persatuan bangsa yang mendiami wilayah Indonesia. Persatuan itu didorong untuk mencapai kehidupan yang bebas dalam wadah negara yang merdeka dan berdaulat.

\section{B Makna dan Pentingnya Persatuan Dan Kesatuan Bangsa}

Kesatuan bangsa Indonesia yang kita rasakan saat ini, itu terjadi dalam proses yang dinamis dan berlangsung lama, karena persatuan dan kesatuan bangsa terbentuk dari proses yang tumbuh dari unsur-unsur sosial budaya masyarakat Indonesia sendiri, yang ditempa dalam jangkauan waktu yang lama sekali.

Unsur-unsur sosial budaya itu antara lain seperti sifat kekeluargaan dan jiwa gotongroyong. Kedua unsur itu merupakan sifat-sifat pokok bangsa Indonesia yang dituntun oleh asas kemanusiaan dan kebudayaan. Karena masuknya kebudayaan dari luar, maka terjadi proses akulturasi (percampuran kebudayaan). Kebudayaan dari luar itu adalah kebudayaan Hindu, Islam, Kristen dan unsur-unsur kebudayaan lain yang beraneka ragam. Semua unsur-unsur kebudayaan dari luar yang masuk diseleksi oleh bangsa Indonesia. Kemudian sifat-sifat lain terlihat dalam setiap pengambilan keputusan yang menyangkut kehidupan bersama yang senantiasa dilakukan dengan jalan musyawarah dan mufakat. Hal itulah yang mendorong terwujudnya persatuan bangsa Indonesia. Jadi makna dan pentingnya persatuan dan kesatuan bangsa dapat mewujudkan sifat kekeluargaan, jiwa gotong-royong, musyawarah dan lain sebagainya.

Menurut (Heroick, 2019) ada tahapan dalam pembinaan persatuan bangsa Indonesia itu yang paling menonjol ialah sebagai berikut: 1) Perasaan senasib. 2) Kebangkitan Nasional 3) Sumpah Pemuda 4) Proklamasi Kemerdekaan

\section{Prisip-Prinsip Persatuan Dan Kesatuan Bangsa}

Hal-hal yang berhubungan dengan arti dan makna persatuan Indonesia apabila dikaji lebih jauh, terdapat beberapa prinsip yang juga harus kita hayati serta kita pahami lalu kita amalkan.

\section{Menurut (Annurua \& Nurani, 2019) tentang Prinsip-prinsip itu diantaranya :}

\section{a) Prinsip Bhineka Tunggal Ika}

Prinsip ini mengharuskan kita mengakui bahwa bangsa Indonesia merupakan bangsa yang terdiri dari berbagai suku, bahasa, agama dan adat kebiasaan yang majemuk. Hal ini mewajibkan kita bersatu sebagai bangsa Indonesia.

b) Prinsip Nasioalisme Indonesia 
Kita mencintai bangsa kita, tidak berarti bahwa kita mengagung-agungkan bangsa kita sendiri. Nasionalisme Indonesia tidak berarti bahwa kita merasa lebih unggul daripada bangsa lain. Kita tidak ingin memaksakan kehendak kita kepada bangsa lain, sebab pandangan semacam ini hanya mencelakakan kita. Selain tidak realistis, sikap seperti itu juga bertentangan dengan sila Ketuhanan Yang Maha Esa dan Kemanusiaan yang adil dan beradab.

\section{c) Prinsip Kebebasan yang bertanggung jawab}

Manusia Indonesia adalah makhluk ciptaan Tuhan Yang Maha Esa. Ia memiliki kebebasan dan tanggung jawab tertentu terhadap dirinya, terhadap sesamanya dan dalam hubungannya dengan Tuhan Yang maha Esa.

\section{d) Prinsip Wawasan Nusantara}

Dengan wawasan itu, kedudukan manusia Indonesia ditempatkan dalam kerangka kesatuan politik, sosial, budaya, ekonomi, serta pertahanan keamanan. Dengan wawasan itu manusia Indonesia merasa satu, senasib sepenanggungan, sebangsa dan setanah air, serta mempunyai satu tekad dalam mencapai cita-cita pembangunan nasional.

\section{e) Prinsip Persatuan Pembangunan untuk Mewujudkan Cita-cita Reformasi}

Dengan semangat persatuan Indonesia kita harus dapat mengisi kemerdekaan serta melanjutkan pembangunan menuju masyarakat yang adil dan makmur.

\section{Pengamalan Nilai-nilai Persatuan dan Kesatuan}

Pengamalan Nilai-nilai Persatuan dan Kesatuan antara lain, (Heroick, 2019):

1) Mempertahankan Persatuan dan Kesatuan Wilayah Indonesia. Pepatah mengatakan "bersatu kita teguh, bercerai kita runtuh".

2) Meningkatkan semangat kekeluargaan, gotong-royong dan musyawarah; meningkatkan kualitas hidup bangsa Indonesia dalam berbagai aspek kehidupan

3) Pembangunan yang merata serta berkeadilan sosial bagi seluruh rakyat Indonesia;

4) Memberikan otonomi daerah;

5) Memperkuat sendi-sendi hukum nasional serta adanya kepastian hokum

6) Perlindungan, jaminan serta menjunjung tinggi hak asasi manusia; dan

7) Memperkuat sistem pertahanan dan keamanan sehingga masyarakat merasa terlindungi.

8) Meningkatkan semangat Bhinneka Tunggal Ika.

9) Mengembangkan semangat kekeluargaan.Yang perlu kita lakukan setiap hari usahakan atau "budayakan saling bertegur sapa." 
10) Menghindari penonjolan sara/perbedaan. Karena bangsa Indonesia terdiri dari berbagai macam suku, bahasa, agama serta adat-istiadat kebiasaan yang berbedabeda, maka kita tidak boleh melakukan perbuatan yang dapat menimbulkan perpecahan. Oleh karena itu yang harus kita hindari seperti: Egoisme, Ekstrimisme, Sukuisme, Profinsialisme, acuh tak acuh tidak peduli terhadap lingkungan, fanatisme yang berlebih-lebihan dan lain sebagainya

\section{E Cara Mewujudkan Persatuan dan Kesatuan Bangsa}

Membangun Persatuan dan kesatuan mencakup upaya memperbaiki kondisi kemanusiaan lebih baik dari hari kemarin. Semangat untuk senantiasa memperbaiki kualitas diri ini amat sejalan dengan perlunya menyiapkan diri menghadapi tantangan masa depan yang kian kompetitif.

Pentingnya Pembangunan Moral Melalui Penanaman Nasionalisme di Lingkungan Sekolah, membangun moral dengan nasionalisme harus ditanamkan sejak dini terutama pada siswa usia SD. Usia SD merupakan usia yang tepat untuk penanaman nasionalisme karena anak-anak seusia mereka belum memiliki pergaulan yang kompleks, sehingga masih sangat mudah untuk diarahkan. Dengan pembiasaan di usia SD ini maka penanaman moral akan lebih mudah dan cepat mengakar serta tertanam dalam diri siswa. Sehingga dengan mengambil langkah ini kemugkinan besar penanaman moral akan lebih berhasil dengan baik. (Pianto, 2018)

Sebagai warga negara yang baik hendaknya harus mampu menerapkan cara berpikir nasional sejak dini. Hal itu merupakan cara berpikir seseorang terhadap kesadaran bernegara dan mempunyai ciri-ciri khusus yang diantaranya berupa norma obyektif artinya selalu mengutamakan kepentingan kehidupan nasionalmacu diri, agar terbina persatuan dan kesatuan paling kurang terdapat sepuluh hal yang perlu dilakukan:

1) Berorientasi ke depan dan memiliki perspektif kemajuan;

2) Bersikap realistis, menghargai waktu, konsisten, dan sistematik dalam bekerja;

3) Bersedia terus belajar untuk menghadapi lingkungan yang selalu berubah;

4) Selalu membuat perencanaan;

5) Memiliki keyakinan, segala tindakan mesti konsekuensi;

6) Menyadari dan menghargai harkat dan pendapat orang lain;

7) Rasional dan percaya kepada kemampuan iptek;

8) Menjunjung tinggi keadilan; dan

9) Berorientasi kepada produktivitas, efektivitas dan efisiensi. 


\section{KESIMPULAN}

Segala sesuatu yang kita nikmati keberadaannya kita terima begitu saja tanpa membayangkan betapa sulitnya meraih, antara lain bahasa Indonesia sebagai bahasa persatuan, kemerdekaan, dan pembangunan-pembangunan yang kita nikmati saat ini. Maka, tanggung jawab generasi saat ini terutama sejak sekolah dasar adalah bagaimana mempertahankan apa yang telah ada dan jauh lebih penting lagi mengembangkannya. Untuk mengemban misi itu, kesatuan dan persatuan amat dibutuhkan mengingat begitu banyaknya rintangan-rintangan yang dihadapi bangsa Indonesia. Masalah persatuan dan kesatuan bangsa bukan hanya diperlukan pada saat bangsa Indonesia menghadapi kekuasaan asing saja, melainkan terus diperlukan hingga sekarang, agar kemerdekaan bangsa dan negara yang berhasil dicapai oleh para pendahulu kita tidak digoyah dan hancur di tangan kita. Persatuan dan kesatuan menjadi vaksin penenang keonaran dan kekicruhan kondisi bangsa, sekaligus menjadi harga mati yang harus senantiasa dikedepankan dan dijaga dengan baik.

Sumpah Pemuda mempunyai nilai-nilai strategis yang mendukung ke arah kesatuan dan persatuan bangsa. Kalau sekarang nilai-nilai itu sepertinya terabaikan dalam berbangsa, itu adalah kesalahan dalam menanam dan menumbuhkan nilai. Maka, yang kita butuhkan di masa depan adalah sejarah sebagai pembelajaran moral untuk kepentingan kebangsaan. Masa lalu sebagai pengalaman adalah guru terbaik dan darinya kita dapat melihat kembali, merenungi, memahami, dan memperoleh banyak nilai yang terkandung di dalamnya serta mengaplikasikannya.

"Persatuan dan kesatuan yang dibangun bangsa Indonesia bukanlah uniformasi, dan juga bukan untuk meniadakan kemajemukan masyarakat. Karena itu, harus didasari bahwa persatuan dan kesatuan nasional yang kita inginkan adalah persatuan dan kesatuan yang tetap menghargai pluralisme dan sekaligus menghormati dan memelihara keberagaman yang dimiliki bangsa Indonesia. Atau, dengan kata lain, kita tetap menginginkan adanya Bhinneka Tunggal Ika," Dan kemajemukan masyarakat bukanlah merupakan hambatan atau kendala bagi penguatan persatuan dan kesatuan bangsa, bahkan kemajemukan merupakan potensi dan kekuatan yang amat kaya untuk memajukan bangsa dan negara. 


\section{DAFTAR PUSTAKA}

Annurua, Q. A., \& Nurani, F. (2019). Tanggung Jawab dalam Menjaga Persatuan dan Kesatuan Bangsa Indonesia. Jurnal SSBI Universitas Brawijaya, 1-5.

Heroick, H. (2019). Makalah Tentang Persatuan Dan Kesatuan20191028 37456. Dinamika Persatuan \& Kesatuan Bangsa Dalam Konteks KRI, 10, 5-7.

Pianto, H. A. (2018). Usaha Mengatasi Ancaman Disintegrasi Bangsa dalam Rangka Memupuk Persatuan dan Kesatuan Bangsa Pasca Kemerdekaan. MUKADIMAH: Jurnal Pendidikan, Sejarah, Dan Ilmu-Ilmu Sosial, 1(2), 179-187. https://doi.org/10.30743/mkd.v1i2.517

Kartodirdjo, Sartono, Multidimensi Pembangunan Bangsa: Etos Nasionalisme dan Negara Kesatuan, Yogyakarta, Kanisius, 1999.

Ade Makmur Kartawinata. 1999. Persatuan dan Kesatuan Bangsa: Suatu renungan Pembentukan Indonesia Merdeka Ke Arah Kebudayaan Kebangsaan. Bandung: Primaco Akademika. 